ZalącZnils

DOI 10.21697/zk.2021.8.06

\title{
MIĘDZY METAFORĄ A AFEKTYWNOŚCIĄ. CIAŁO CZUJĄCE W TEKŚCIE
}

Beata Przymuszała

Wydział Filologii Polskiej i Klasycznej UAM

Faculty of Polish and Classical Philology

Adam Mickiewicz University in Poznań

beaprzy@amu.edu.pl

ORCID: 0000-0002-8915-748X

Zbierając swoje wieloletnie badania w książce Somatopoetyka - afekty wyobrażenia. Literatura XX i XXI wieku, Anna Łebkowska zauważa, iż nowym badaniom nie zagraża swego rodzaju „pancielesność”, są one bowiem świadome niejednoznacznego statusu ludzkiej fizyczności, która nie pozwala sprowadzić się do czystej materialności ${ }^{1}$. Jak podkreśla:

Uchwycenie cielesności za pomocą określania jej jak tego, co przedkulturowe, bądź jak tego, co kształtowane w danej formacji przez kulturę, innymi słowy: dookreślone przez jej dyskurs i zarazem przez tenże dyskurs wypierane - wszystkie te sposoby „dotknięcia” czy właśnie uchwycenia cielesności nie stanowią rozpoznań zakończonych czy oczywistych².

Przywoływane przez badaczkę zmiany postrzegania cielesności wiążą się z nieustanną refleksją nad kulturą, a doprecyzowując - można powiedzieć, że wciąż przekształcające się rozumienie cielesności pozwala inaczej czytać i odczuwać pozwalającą jej się artykułować tekstowość. W tym też kontekście Łebkowska trafnie zwraca uwagę na specjalny charakter synestezji: tropu, który wymaga ponownego oglądu relacji między zmysłowym odczuwaniem a językowym wyrażaniem. W swojej książce podkreśla, iż najbardziej ekspansywne dziewiętnastowieczne jej rozumienie koncentrowało się na korespondencji sztuk i mistycznym jej postrzeganiu; ten spirytualizm

${ }^{1}$ A. Łebkowska, Somatopoetyka - afekty - wyobrażenia. Literatura XX i XXI wieku, Kraków 2019. s. 37.

2 Ibidem, s. 31-31. 
jednak pomijał materialne podłoże odczuwania. Zmiana, która dokonała się ostatnio, polegać ma przede wszystkim na „zakotwiczeniu zmysłów w cielesności właśnie”, co umożliwia łączenie/przeplatanie sensualnego, językowego, sensownego ${ }^{3}$.

Chcę przyjrzeć się temu przekształceniu, zwracając uwagę na to, jak trop synestezyjny staje się tropem odczuwania rzeczywistości. Jej odczuwanie z kolei wymaga zwrócenia uwagi na to, co pozwala się „ujęzykowić” - i nie chodzi tu tylko o językową dostępność, ale o sposób rozumienia języka (i tekstu) w ogóle.

W nowszych pracach poświęconych synestezji jest ona postrzegana jako rodzaj wielkiej metafory pozwalającej ująć różnorodność ludzkiego doświadczenia (tak postrzega ją Elżbieta Stachowiak, analizując jej rolę w literaturze i posiłkując się myślą Marka Johnsona ${ }^{4}$ ). Jako synestezyjne postrzegane bywają także rozmaite przeżycia związane z wielozmysłowym odczuwaniem, wspominaniem ${ }^{5}$. Poszerza się również możliwość zmysłowych połączeń: poszczególne doznania - takie jak smak, dźwięki, dotyk - wyobrażone znaczenia słów mogą wiązać się z jednoczesnym ich przeżywaniem jako wrażeń barwnych, zapachowych, smakowych, dotykowych, wizualnych ${ }^{6}$. Jeśli jednak synestezja jako trop była traktowana przede wszystkim jako „barwne słyszenie”, to ostatnio najczęściej analizowane są relacje między wzrokiem a dotykiem7. Można powiedzieć, że dotykając, widzę i zarazem wzrokiem dotykam. Ktoś może być dotknięty czyimś spojrzeniem - metaforyczność wyrażenia jest i nie jest w tym przypadku widoczna (tym mniej jest widoczna, im bardziej akcentujemy sprawczość niewerbalnej komunikacji - w tych przypadkach ktoś rzeczywiście jest zraniony, dotknięty czyimś wzrokiem).

3 Ibidem, s. 36-37.

4 E. Stachowiak, Alchemia stów. Zjawisko synestezji w literaturze. [w:] Materialność i sensualność tekstu, red. J. Bedyniaka. Warszawa 2018.

5 A. Ginter, Vladimir Nabokow i jego synestezyjny świat, Łódź 2015, s. 10.

6 Ibidem.

7 Zob. A. Łebkowska, Afirmacja dotyku w dyskursie współczesności, [w:] W kulturze dotyku? Dotyk i jego reprezentacje w tekstach kultury, red. A. Łebkowska, Ł. Wróblewski, P. Badysiak, Kraków 2016, s. 10. 
W klasycznym już eseju Oczy skóry. Architektura i zmysły Juhani Pallasmaa wskazując, w jak de facto zmysłowy sposób odbieramy przestrzeń, pokazywał zarazem, na czym polega proces intelektualizacji naszych doświadczeń. Różnorodność doznań zostaje ograniczona, uporządkowana i podporządkowana formie, która $z$ naszej perspektywy doznawania odsuwa sensualność wrażeń. Postulując radykalną zmianę myślenia o architekturze, autor omawianego eseju zauważa:

Dotyk jest zmysłem, który integruje nasze doświadczenie świata i nas samych. [...] Wszystkie zmysły, łącznie ze wzrokiem, są przedłużeniami zmysłu dotyku, zmysły są specjalizacjami tkanki skórnej, a wszystkie doświadczenia sensoryczne są sposobami dotykania i jako takie są związane z taktylnością. Nasz kontakt ze światem odbywa się na granicy podmiotu, poprzez wyspecjalizowane części pokrywającej nas membrany.

Jest oczywiste, że „poprawiająca/wzmacniająca życie” architektura musi zwrócić się jednocześnie do wszystkich zmysłów i pomóc w połączeniu naszego obrazu samych siebie z doświadczaniem świata. [...] Architektura nie sprawia, że zamieszkujemy wyłącznie światy wytworów i zmyśleń, ale służy artykulacji naszego doświadczenia bycia w świecie oraz wzmacnia nasze poczucie realności i podmiotowości ${ }^{8}$.

Dotyk wiąże się z podstawowym funkcjonowaniem, a precyzyjniej ujmując: jest podstawą istnienia, pozwala zakreślić własne granice i doświadczyć innych (granic i osób). Jeszcze inaczej prymarny charakter tego zmysłu staje się widoczny po odkryciu jego obecności w innych sensualnych doznaniach: jeśli wszystkie zmysły korzystają z mapy zakreślonej przez cielesne doświadczenia, to nie da się ich przecież mocno rozdzielać. Należy też zwrócić uwagę na sposób, w jaki cielesność prezentuje się jako nieodzowny komponent wszelkich przeżyć. Jak odpowiednio dobrany układ domu czy mieszkania służy naszym potrzebom do tego stopnia, że przestaje być zauważany, tak właśnie dopiero jego zmiana, utrudniając życie, uświadamia, jak ważna była i jest ta przezroczysta jego obecność. „Przezroczysta” nie w ujęciu braku obecności, niematerialności, ale rozumiana jako oczywista i w tym znaczeniu niewidoczna. Pallasmaa podkreśla znaczenie materialności jako

8 J. Pallasmaa, Oczy skóry. Architektura i zmysły, tłum. M. Choptiany, Kraków 2012, s. 15-16. 
komponentu naszego poznawania, łącząc możliwość doświadczania architektury z diagnozą naszych czasów:

Nadmierna koncentracja na intelektualnych i konceptualnych aspektach architektury przyczynia się do zaniku jej fizycznego, zmysłowego i cielesnego charakteru. [...] Poza architekturą, kultura współczesna jako taka dryfuje ku pewnej dystansującej, schładzającej desensualizacji i deerotyzacji związku człowieka z rzeczywistością9

Architekt jest przy tym świadomy, iż tego typu spostrzeżenie może zostać potraktowane jako rodzaj konserwatywnej - w ujęciu nienadążającej za istotnymi przemianami - oceny nowej sztuki i dlatego zastrzega:

Sugeruję jedynie, że zaszła znacząca zmiana w naszym sensorycznym i percepcyjnym doświadczeniu świata i że znajduje ona swoje odbicie w sztuce i architekturze. Jeśli pragniemy, aby architektura miała emancypującą lub i uzdrawiającą rolę zamiast wzmagać erozję egzystencjalnego znaczenia, musimy zastanowić się nad wielością tajemnych ścieżek, które prowadzą od sztuki architektury do kulturowej i mentalnej rzeczywistości naszych czasów ${ }^{10}$.

Pisząc o związku między architekturą a sztuką Pallasmaa pisze de facto o relacji między doświadczeniem przestrzeni i poczuciem własnej cielesności a jej wyrażaniem, prezentowaniem. Nie bez racji przypomina przy tym, iż kwestia postrzegania siebie - szeroko ujmowana - jako świadomość własnej osoby wsparta na materialnym związku z otoczeniem, czerpiąca z rzeczywistości i otwarta na jej różnorodne doznawanie (o sensualnym przede wszystkim charakterze) wpływa na kształt kultury (co później zostaje jeszcze szczególnie wzmocnione kształtowaniem norm estetycznych, mających z kolei wpływ na egzystencjalne doznania).

Dostrzeżenie i zrozumie prymarnego sensu ciała kształtuje w nowoczesności najpierw delikatną, ale z czasem coraz mocniej widoczną linię wyraźnie zaznaczającą się we współczesnych naukowych dyskursach. Podejmowane badania zaczynają potwierdzać, na czym polega tak istotna rola cielesności i wyjaśniać znaczenia, jakie jej odczuwanie ma dla ludzkiego

\footnotetext{
9 Ibidem, s. 41.

10 Ibidem, s. 43 .
} 
rozwoju. Czucie siebie wiąże się z receptywnością naszej skóry: dotyk jest zmysłem umożliwiającym rozwój dziecka przed jego narodzeniem i stabilizującym jego stan po przyjściu na świat. Tym samym jest zmysłem - co intuicja humanistów wcześniej formułowała - o podstawowym dla ludzkiego przetrwania znaczeniu. W książce Homo hapticus. Dlaczego nie możemy żyć bez zmysłu dotyku Martin Grunwald zauważa, iż bez dotyku nie możemy uświadomić sobie swojego istnienia: „Nie myślimy siebie, my siebie czujemy ${ }^{11}$ ”. I właśnie z psychologicznej perspektywy, na podstawie prowadzonych badań stwierdza, że zmysły słuchu, wzroku, węchu i smaku pozwalają nam na bardziej precyzyjne poznawanie świata, natomiast jakiekolwiek ich zaburzenie nie zagraża naszemu życiu. Zupełnie inaczej natomiast jest w przypadku zmysłu dotyku. Jest to pierwszy ze zmysłów, który pojawia się kilka tygodni po zapłodnieniu i którego intensywny rozwój towarzyszy intensywnemu rozwojowi dziecka. Rozważając jego rolę, badacze zaznaczają, iż nie sprowadza się ona jedynie do ochrony płodu, lecz ma znaczenie dla rozwoju poczucia własnej świadomości: „Chociaż schemat ciała płodu i noworodka znajdują się w początkowej fazie rozwoju, to jednak stanowi konieczny fundament każdego skoordynowanego ruchu, a później kształtowania się świadomości własnego »ja«! "2". Prymarność dotyku ma więc nie tylko znaczenie poznawcze, ale i egzystencjalne. Poznawczo natomiast wiąże się ze specyficznym ukształtowaniem zmysłów:

Narząd słuchu zbudowany jest niewątpliwie na wzór układu dotyku. Słyszenie to $\mathrm{w}$ istocie zdolność wychwytywania i przekazywania do mózgu drgań mechanicznych o różnej częstotliwości [...]. Z tego powodu słuch jest wyspecjalizowaną, ograniczoną do określonego obszaru ciała, formą percepcji dotykowej ${ }^{13}$.

Ta zależność pozostałych zmysłów od dotyku długo jednak nie była uświadamiana, trudno też było z pewnością do niedawna jeszcze przyjmować, iż to od wykształcenia zdolności odczuwania zależy samo nasze istnienie. Jak zaznacza Grunwald, zdolność zmysłu dotyku do odbierania

${ }_{11}$ M. Grunwald, Homo hapticus. Dlaczego nie możemy żyć bez zmysłu wzroku, tłum. E. Kowynia, Kraków 2019, s. 12.

12 Ibidem, s. 23-36.

13 Ibidem, s. 28-29. 
bodźców stwarza podstawę do adaptacji w świecie i umożliwia przetrwanie. Konkludując, podkreśla: „im więcej jestem w stanie odczuć, tym większe mam szanse na przeżycie ${ }^{14 "}$.

Dotyk pozwala więc żyć i eksploatować świat, a skóra, dzięki której dotyk staje się możliwy, pozwala zarazem odczuć kolory, zapachy, dźwięki i smaki. Tak autor Homo hapticus komentuje analogiczny charakter zmysłu dotyku i słuchu, przypominając, iż określenie „przeszedł mi dreszcz po plecach”, opisujące odbiór muzyki, wynika z podobnego odczuwania: aparat słuchowy zostaje „dotknięty” wibracjami (ponieważ „wrażenie słuchowe to nic innego jak specyficzny sposób kontaktu fizycznego ${ }^{15 ”}$ ). A Pallasmaa dopowiada:

Oczy pragną współpracować z pozostałymi zmysłami. Wszystkie zmysły, z wzrokiem włącznie, mogą być postrzegane jako przedłużenie zmysłu dotyku, jako specjalizacje skóry. Definiują one interfejs pomiędzy skórą i środowiskiem: pomiędzy nieprzejrzystym wnętrzem ciała i światem zewnętrznym ${ }^{16}$.

Traktując poszczególne przypadki synestezyjnego doświadczania rzeczywistości jako mniej lub bardziej wyjątkowe, nie możemy pomijać tych doznań, które się upowszechniły, stając się niemal niezauważalne (jak bywa w przypadku cielesnych reakcji typu „gęsia skórka” związanych z słuchaniem czy oglądaniem). I na ten kontekst właśnie chcę zwrócić uwagę.

Istotne jest przyjrzenie się relacji między postrzeganiem własnego ciała i możliwością współdziałania przy jego pomocy z otoczeniem (współdziałania właśnie, a nie wiążącego się z dominacją panowania). Widoczne jest to w sytuacjach, w których nasze cielesne predyspozycje mają znaczenie dla wykonywania przez nas określonych czynności (taniec, pływanie, prowadzenie samochodu). Współpracujemy z otoczeniem, odczuwamy otaczającą nas przestrzeń, a to, co widzimy, słyszymy, wąchamy przekłada się na reakcje ciała. „Wielki muzyk gra raczej na sobie niż na instrumencie, podobnie jak zdolny piłkarz gra całym sobą, pozostałymi graczami oraz zinternalizowanym i ucieleśnionym boiskiem, a nie wyłącznie kopie piłkę" - to przekonanie Pallasmaa przenosi na doświadczanie architektury i sztuki, pisząc, iż:

\footnotetext{
14 Ibidem, s. 29.

15 Ibidem.

16 J. Pallasmaa, op. cit., s. 51-52.
} 
Kiedy doświadczamy budowli, nieświadomie naśladujemy jej strukturę naszymi kośćmi i mięśniami: przyjemnie żywa muzyka jest podświadomie przekształcana we wrażenia cielesne, kompozycja abstrakcyjnego obrazu jest odczuwana jako napięcie w mięśniach, struktura budynku zaś jest nieświadomie naśladowana i ujmowana przez układ kostno-szkieletowy ${ }^{17}$.

Podobny sposób myślenia o naszej cielesności pojawił się w Traktacie o łuskaniu fasoli Wiesława Myśliwskiego ${ }^{18}$. Jej bohater wciąż znajduje się może lepiej - trafia na sytuacje, w których nie potrafi się odnaleźć. Tak, jakby jego ciało nie nadążało za nim. Jakby tkwiło w przeszłości i nie potrafiło zareagować na to, co mu się właśnie zdarza. Nie umie się zgrać sam ze sobą. Mówi mu o tym nauczyciel gry na saksofonie, podkreślający, iż gra tak, jakby używał narzędzia, a nie tworzył muzykę. Z wyrzutem zaznacza: „Musisz całym sobą grać, także swoim bólem, swoim płaczem, swoim śmiechem, nadziejami, snami, wszystkim, co jest w tobie, całym swoim życiem. Bo to wszystko muzyka"19. I na ten sam problem - niezgrania się z sobą, braku panowania nad własnym ciałem - wskazuje później sprzedawca kapeluszy odradzając model, który bohater dla siebie wybrał:

Nie na miarę jest pańskim powołaniem, żeby tak powiedzieć, znamieniem pańskiego istnienia, co się ujawniło w tym jakże złośliwym przypadku, że jest tylko ten jeden brązowy, pilśniowy kapelusz, i to na wystawie, a z wystawy nie mogę go zdjąć. W dodatku za duży na pana. Wszystko, wszystko jest w panu nie na miarę, co tylko może być nie na miarę w człowieku ${ }^{20}$.

Bohater powieści nie czuje muzyki, nie potrafi zaprezentować sam siebie przy pomocy gestów, i - jak sam opowiadał - niezbyt chętnie też tańczy. Można powiedzieć, że świat stawia mu opór, ale też on sam nie znając, nie czując siebie, nie jest w stanie wejść w interakcje z otoczeniem. Przyczyny

17 Ibidem, s. 78.

18 Przytaczam tu najważniejsze uwagi dotyczące tej powieści Myśliwskiego, bardziej szczegółowo omawiałam ją w tekście „Odczuwać ciało” - motoryka w „Traktacie o łuskaniu fasoli” Wiesława Myśliwskiego przygotowanym w ramach projektu „Sensualność w kulturze polskiej" kierowanego przez prof. dra hab. Włodzimierza Boleckiego (www. sensulanosc.bn.org.pl).

19 W. Myśliwski, Traktat o łuskaniu fasoli, Kraków 2006, s. 223.

20 Ibidem, s. 326. 
takiego zachowania wiążą się z traumą doznaną w dzieciństwie: utrata całej rodziny spowoduje najpierw długotrwałe milczenie chłopca, a później będzie widoczna w braku harmonii między doznaniami a ich odczuwaniem. Potraumatyczne zamrożenie, wycofanie się, brak kontaktu z własnymi doświadczeniami pozwala przetrwać, uniemożliwiając jednak pełne życie. I co istotne: powrót do życia wiąże się u młodego mężczyzny z próbą gry na instrumencie i zarazem z próbą powrotu mowy:

Wszystkiego się bałem, ludzi, rzeczy, słów. [...] Najprostsze słowo mnie bolało i każde odczuwałem jak nie swoje własne.

Kiedy wszyscy na sali już posnęli, nakrywałem się z głową kocem i przepytywałem szeptem sam siebie $\mathrm{z}$ takich, innych słów, jakbym się od początku ich uczył, obłaskawiał je, przyzwyczajał się, że to moje słowa.

Czemu w łóżku to robiłem, nakrywając się w dodatku kocem? Nie wiem. Może słowa potrzebują ciepła, gdy się rodzą od nowa. [...]

Dopiero dzięki temu, że zacząłem się uczyć grać, odzyskałem z wolna mowę, a tym samym poczucie, że żyję. W każdym razie nie zacinałem się już tak i słów mi zaczęło przybywać, i coraz mniej się tych słów bałem² ${ }^{21}$.

Mowa jest więc mocno związana z ogólną kondycją ciała. Psychologia rozwoju dziecka wprawdzie dopiero niedawno zaczęła przyglądać się związkowi między mówieniem a zdolnościami motorycznymi i czuciowymi, chociaż dużo wcześniej już obserwowano, iż - jak referuje Martin Grunwald: „dzieci $\mathrm{w}$ wieku przedszkolnym, które mają trudności z mówieniem, przejawiają duże problemy z właściwą interpretacją bodźców uciskowych, wibracyjnych i ruchowych" 22 .

Ucieleśnienie mowy odwołuje się więc dosłownie - nie metaforycznie - do procesów rozwojowych i artykułowanie głosek, wyrazów, fraz jest mocno osadzone w zdolności czucia własnego ciała. Język nie jest w tym przypadku zbyt zręczny, stawia opór przed wyjaśnieniem prostego faktu, że mówię własnym ciałem, że jego możliwości odczuwania umożliwiają mi

${ }^{21}$ Ibidem, s. 97.

22 M. Grunwald, op. cit., s. 69. Wynika to z faktu dominacji sfery dotyku jako sposobu poznawania rzeczywistości w pierwszym okresie życia dziecka. Zaburzenie tej strefy utrudnia procesy uczenia się, zapamiętywania oraz mówienia - zob. ibidem, s. 68-69. 
wysławianie się. A przecież pojawia się tu doświadczenie tak dobrze znane, że zapominane. Wrażenie, że brakuje mi potrzebnego słowa jest przeze mnie odczuwane jak rodzaj dyskomfortu. Czasem pomagają gesty - jakby łapały słowo za słowo, czasem trzeba się poruszyć, obrócić, czego dotknąć - jakbyśmy sobą szukali tych słów. Bohater powieści Myśliwskiego wyszeptywał je sobie, najpierw siebie samego otulając: nieprzypadkowo nie akcentuje on potrzeby izolacji od innych śpiących młodych mężczyzn, ale wskazuje na ciepło, które towarzyszy bliskości (zapewniając bezpieczeństwo pozwala otworzyć się na świat). Ucieleśnione słowa pozwalają się odczuć. Opis tego doznania koresponduje z refleksją Marka Johnsona, który tak komentuje moment, w którym przestajemy mówić lub pisać, by znaleźć właściwe słowo:

Odczuwamy rodzaj frustracji, napięcia i zakłócenia, które są stresujące. Słowa płynęły swobodnie i dobrze, i nagle [...] przychodzi potknięcie albo wstrzymanie. Owo „zatrzymanie” odczuwamy w pewien sposób i ten sposób jest zupełnie różny od swobodnego przepływu myśli, który nastąpił wcześniej. Zatrzymany ruch naszej myśli albo napięcie dominujące nasze myślenie staje się nieprzyjemnym zakłóceniem w nas samych. Jedynie wtedy, gdy znajdziemy słowa, które pociągną dalej znaczenie, właśnie próbnie artykułowane, poczujemy ulgę będącą skutkiem pokonania trudności $[\ldots]^{23}$.

Słowa, które czujemy wskazują na mocno zakorzeniony w ciele proces poznawania rzeczywistości, który stanowi istotną bazę naszych zdolności eksplorowania świata. Ciałem poznajemy nawet wtedy, gdy wydaje się nam, że potrafimy wznieść się ponad nie. Zwłaszcza wtedy, ponieważ wciąż unosimy się nad nim.

Szczególnie taki sposób poznawania został wyeksponowany w kluczowym motywie kompozycyjnym ostatniej powieści Myśliwskiego. Jeśli w Traktacie o łuskaniu fasoli były zaprezentowane synestezyjne ujęcia różnych czynności związanych z odczuwaniem siebie, poruszaniem się i możliwością mówienia, to w Uchu igielnym pojawia się silny związek między rozumieniem (ujmowanym jako konceptualizowanie rzeczywistości) a panowaniem nad własnym ciałem i pamięcią.

${ }^{23}$ M. Jonhson, Znaczenie ciała. Estetyka rozumienia ludzkiego, tłum. J. Płuciennik, Łódź 2015, s 98. 
Otwierająca powieść scena rozmowy młodego człowieka ze starszym już mężczyzną to spotkanie z sobą samym sobą - odległym, trudnym do zrozumienia, niemal obcym. Pokonywanie schodów - sposób jego ujmowania (mentalnego) i podejmowania (fizycznego) - stanowią próby synestezyjnego łączenia cielesnego przeżycia z poczuciem siebie i rozpoznaniem własnego losu:

Sprawdzał laską kolejny schodek, ale jakby nie wierzył lasce, bo jeździł jej końcem po tym schodku w lewo, w prawo, zanim postawił stopę. Chciałem go spytać, po co w takim razie schodzi do tej dawnej dzikiej, zielonej doliny, lecz uprzedził mnie:

- Współczuję panu, że pan musi dalej żyć. Ale może będzie pan miał więcej szczęścia. Życzę panu. Chociaż, moim zdaniem, z życzeń jeszcze nic dla nikogo nie wynikło. - Zszedł na kolejny schodek, tak samo sprawdzając go laską. - Prawdę mówiąc, każde życie jest powtarzaniem życia po kimś. Przeszłość nas wyprzedza, musi pan to wiedzieć, ciągniemy się za nią. Bo któż by nadążył za swoim życiem. - Zatrzymał się na kolejnym schodku. - O, ileż tędy nóg musiało przejść. Zwrócił pan uwagę, jak wytarte są te schody ${ }^{24}$ ?

Patrząc na siebie z perspektywy własnej młodości dostrzega przede wszystkim niepewność, chwiejność - niemożność pewnego postawienia kroku połączona zostaje z przekonaniem o konieczności wejścia w miejsce już „wydeptane” (bezpieczne? znane? dające siłę?): schodzenie jest związane z szukaniem swojego miejsca i szukaniem siebie (szukaniem - forma niedokonana jest w tym przypadku istotna). Patrząc na siebie młodego, dojrzały mężczyzna dostrzega z kolei niemożność zatrzymania się, brak potrzeby umiejscowienia:

Wtem $\mathrm{z}$ tego niewidocznego gdzieś tam, w dole, końca ktoś długimi susami, właśnie po dwa, trzy schodki, jak ja kiedyś, biegnie w górę ku mnie. Już jest blisko, niewiele schodków nas dzieli, poznaję go, jakże mógłbym go nie poznać, szukam słów, którymi chciałbym go powitać. Ktoś nas rozdziela, schodząc [...]. Mimo to zbliżamy się do siebie, on już jest w Uchu Igielnym, a ja mam nieledwie trzy, cztery schodki do niego. Przepuszcza kogoś, kto właśnie wychodził, natomiast mnie jakby nie miał zamiaru przepuścić. Stoi pośrodku tego Igielnego Ucha i wpatruje się nieufnie we mnie, jakby się tym

24 W. Myśliwski, Ucho igielne, Kraków 2018, s. 8-9. 
wzrokiem pytał, a pan kto? Domyślam się, że mnie nie poznaje, i nie dziwię się, bo jakże może mnie poznać z takiej odległości lat [... ${ }^{25}$.

Nie mogą się minąć (są sobie zbyt bliscy) i nie mogą się dotknąć (są sobie zbyt obcy) - schodzenie i wchodzenie po schodach, przeskoki i chwiejny krok, otwarta perspektywa (kierowane spojrzenie ku górze) i zamykający widok dół schodów. Próba rozpoznania siebie w sobie to zderzenie absolutnie odmiennych punktów widzenia, tak, jakby można jednocześnie wchodzić i schodzić z tych samym schodów. A przecież staną nagle obok siebie młody mężczyzna i starszy pan - nie będą potrafili się jednak zrozumieć.

Przemijanie i próba dostrzeżenia własnej historii (rozpoznania tożsamości) nie są tu zaprezentowane jako linearne przejście, linearne (kumulatywne) uzyskiwanie wiedzy o sobie. To raczej zderzanie ze sobą nieprzystawalnych lub po prostu mocno oddalonych światów, które nie są przekonane do zasadności odmiennego punktu widzenia, które wzajemnie siebie odgraniczają. I w tym zderzeniu jedynie (zderzeniu poczucia niemożliwego bycia sobą teraz i sprzed lat) pojawić się może ledwie artykułowane poczucie bycia sobą: jakbyśmy doświadczali zjawiska nieprzystawalności wzroku i cielesnego poczucia przestrzeni. Widzimy niemożliwą jednoczesność tego, co nieprzystawalne - jak na wstędze Möbiusa. Odczuwamy, że łudzi nas wzrok, a przecież czujemy, że jesteśmy obok siebie: patrzymy przecież n a siebie sprzed lat. Opowieść o sobie - w tym znaczeniu - najczęściej bywa opowieścią prawie niemożliwą. Nie potrafimy jednak inaczej o sobie (o sobie?) opowiedzieć. Czujemy, że to, co mówimy, mówimy, stojąc w zupełnie innym miejscu. Powieściowy główny motyw pozwala nam doznać niezborności snucia historii o własnym życiu, o byciu sobą i jednocześnie poczuć zdziwieniebędące efektem rozpoznania wzrokowego złudzenia: widzimy przecież siebie i nie/siebie jednocześnie i jednocześnie czujemy się sobą i nie/sobą.

Zwrócenie uwagi na ten sposób myślenia o sensualnych aspektach wypowiedzi - o odczuwaniu własnej opowieści oraz cielesnym aspekcie formy opowieści - stanowi wyzwanie dla badań nad czysto językowym ujmowaniem tekstu: słowa, które pozwalają się poczuć, stawiają opór także badawczym przyzwyczajeniom, prowokują do uaktywnienia lektury afektywnej,

25 Ibidem, s. 58. 
w tym zwłaszcza analiz koncepcji tworzenia nastroju przez teksty. Jest to nowy, pobudzający do odczuwania, sposób lektury.

\section{Bibliografia}

Anna Ginter, Vladimir Nabokow i jego synestezyjny świat, Wydawnictwo UŁ, Łódź 2015. Martin Grunwald, Homo hapticus. Dlaczego nie możemy żyć bez zmysłu wzroku, tłum.

E. Kowynia, Wydawnictwo UJ, Kraków 2019.

Mark Jonhson, Znaczenie ciała. Estetyka rozumienia ludzkiego, tłum. J. Płuciennik, Wydawnictwo UŁ, Łódź 2015.

Anna Łebkowska, Afirmacja dotyku w dyskursie współczesności, [w:] W kulturze dotyku?

Dotyk i jego reprezentacje $w$ tekstach kultury, red. A. Łebkowska, Ł. Wróblewski, P. Badysiak, Nomos, Kraków 2016.

Anna Łebkowska, Somatopoetyka - afekty - wyobrażenia. Literatura XX i XXI wieku, Wydawnictwo UJ, Kraków 2019.

Władysław Myśliwski, Traktat o łuskaniu fasoli, Znak, Kraków 2006.

Władysław Myśliwski, Ucho igielne, Znak, Kraków 2018.

Juhanni Pallasmaa, Oczy skóry. Architektura i zmysły, tłum. M. Choptiany, Instytut Architektury, Kraków 2012.

Elżbieta Stachowiak, Alchemia słów. Zjawisko synestezji w literaturze, [w:] Materialność i sensualność tekstu, red. J. Bedyniak, IBL PAN, Warszawa 2018.

\section{Źródła internetowe}

Beata Przymuszała, „Odczuwać ciało” - motoryka w "Traktacie o łuskaniu fasoli” Wiesława Myśliwskiego, Sensualność w kulturze polskiej, www.sensulanosc. bn.org.pl [dostęp 6.09.2019].

\section{Between Metaphor and Affectivity. The Sentient Body in the Text}

This article discusses the breakthrough of the change in talking about synesthesia. Highlighting the bodily aspect of imaging allows to combine the linguistic, psychological and artistic context. By discussing selected images from Myśliwski's novel, the author shows how the material/sensual aspect of the description allows the recipients to feel the presented situation and at the same time rethink their own thinking (feel their own thinking).

Keywords: synesthesia, body, language, thinking

Data otrzymania tekstu: 1.04.2020 r.

Data zakończenia procesu recenzyjnego: 15.02.2021 r.

Data akceptacji tekstu do druku: 22.02.2021 r. 